\title{
MARINE EXPOSURE TESTS OF COCONUT TIMBER
}

\author{
R. N. Palomar ${ }^{1}$
}

\section{SUMMARY}

Marine exposure tests of sawn coconut lumber were carried out for three years to determine the resistance, of treated coconut timber to marine borers.

The test panels measuzing $50 \mathrm{~mm}$ x $100 \mathrm{~mm} \times 450 \mathrm{~mm}$, were installed in sea water between October, 1981 and September, 1984. Results showed three promising treatments. These were the vacuum/pressure method using chromated copper arsenate, the modifted double diffusion treatment employing mixture of copper adphate, sodium dichromate and arsenic pentoxide, and the hot and cold bath treatment with coal tar creosote. The specimens treated by these preservative systems showed trace or slight surface infestation while the untreated wood panels indicated from deep and extensive infestation to failure due to attack of marine borers.

The perfommnce of the treated medium density specimens appeared to be inferior than the hard samples indicating that only the latter materials should be used for marine structures.

\section{INTRODUCTION}

In the Philippines, conventional timbers are often used as piles for building wharf, marina, jetty and other structures in contact with coastal water. The possibility of utilizing coconut timber for marine piles should be equally explored considering its availability at replanting time. In fact piles and foundation posts of some marine structures today are mide of round coconut timber. However, their service life is limited due to the fact that most, if not all, are installed untreated which readlly attack by marine pests. If these piles are not properly protected from pests they will eventuaffy create problems in service which ultimately lead to costly repair and maintenance.

Most coastal waters are infested with wood attacking pests collectively known as manne borers. Apparently, they are especially destructive in tropical and warm-water regions (Hockman, 1973).

There are two main groups of marine borers responsible for biological deterioration of wooden marine structures. They are the molluscan borers which are distantly related to oysters and clams, and the crustacean, borers which are related to lobsters and crabs (Hunt and Garrat, 1967). The most important genera of wood destroying mollusks are Teredo, Bankia and Martesia The first two genera, are also known as ship-worms while Martesia borers resemble clams. The crustacean borers belong to, the genera Limnoria, Sphaeroma and Chelum. In the Philippine waters, marine borers that are active are the shipworms, Martesid and Limnoria (Siriban, et al, 1976).

Sea water exposure tests conducted in the Philippines by Siriban, et al (1976) on apitong heartwood samples pressure treated with creosote and chromated copper arsenate showed that untreated specimens were $75 \%$ deteriorated after 9 months versus treated specimens after 3.5 to 4.75 years. Specimens treated with water-borne preservative performed as well as those treated with creosote.

\footnotetext{
${ }^{1}$ Chief Timber Utilization Division, Zamboanga, Research Center. Philippine Coconut Authority, P.O. Box 356 Zamboanga City, Philippines.
} 
Test in Taiwan (Wang and Hsieh, 1976) revealed that untreated woods were badly damaged by marine borers in 3-6 months. However, several preservatives gave good protection on wood puticularly the standard creosote, and a mixture of creosote and Tanalith $\mathrm{C}$.

Field trials in Italy (Gambetta and Orlandt 1976) indicated that Pinus Sylvestris sapwood swnples appeared to show greatest resistance, to attack by marine, borers when pressure treated with either copper-chrome-borate or copper-chrome-fluoride.

In India (Santhakumaran, 19771 tests were made to determine the incidence of marine borers in relation to the position of the panels in sea water. The specimens used were Mangipera indica panels and were fixed horizontally, vertically and an angle of $45^{\circ}$ at mud level and 2 meters above the mud. After incubations of 42-77 days, the incidence of marine borers were greatest on horizontal panels and least on the vertical panels.

Tests in the United States (Richards, 1978) revealed that after 12 years of sea water exposure, pine and fir panels treated with copper-chrome-arsenate, ammoniacal copper-chrome-arsenate and a combination of copper-chrome-arsenate and creosote were found to, be satisfactory from protection against aittack of marine borers.

Timber structures in sea, water require protection from attack of marine borers to obtain optimum service life. Hence, this study was designed to, examine the resistance of treated coconut timber to marine borers under Philippine condition.

\section{MATERIALS AND METHODS}

The test panels, measuring $50 \mathrm{~mm} \times 100 \mathrm{~mm} \times 450 \mathrm{~mm}$, consisted of 24 pieces high density and 24 pieces medium density sawn coconut lumber.

The preservatives used were chromated copper arsenate (CCA), copper sulfate $\left(\mathrm{CUSO}_{4}\right)$, chrome-arsenate (CrAs) and coal tar creosote (CTC).

The experiment consisted of 8 treatments arranged in a Completely Randomized Design with 3 replications for both high and medium density panels. The treatments are as follows :

\section{Treatments}

$\mathrm{T}_{1}$ - CCA

$\mathrm{T}_{2}-\mathrm{CUSO} 4+\mathrm{CrAS}$

$\mathrm{T}_{3}-\mathrm{CUSO} 4+\mathrm{CrAS}$

$\mathrm{T}_{4}-\mathrm{CTC}$

$\mathrm{T}_{5}-\mathrm{CCA} / \mathrm{CTC}$

$\mathrm{T}_{6}-\mathrm{CUSO}+$

CrAs/CTC

$\mathrm{T}_{7}-\mathrm{CUSO} 4+$

CrAs/CTC

$\mathrm{T}_{8}$ - Control

\section{Method of preservative application}

Pressure impregnation

Double diffusion

Modified double diffusion

Hot and cold bath

Pressure impregnation/hot and cold bath

Double diffusion/hot and cold bath

Modified double diffusion/hot and cold

bath.

Untreated

The sample boards were air dried to equilibrium moisture content prior to treatment.

Schedule of treatment for pressure impregnation was as follows: 1st vacuum of -85 Kpa, 30 minutes; pressure of $1400 \mathrm{Kpa}, 1$ 1/2 hours and 2nd vacuum, 5 minutes. 
For the double diffusion treatment the panels were soaked in a cold bath of $5 \%$ copper sulphate for 24 hours followed by second soaking in 5\% mixture of sodium dichromate and arsenic pentoxide solution for 4 days.

The modified double diffusion treatment involved soaking of wood samples in hot bath $\left(50-60^{\circ} \mathrm{C}\right)$ of $5 \%$ copper sulphate for 6 hours and subsequently second dipping in $5 \%$ mixture of sodium dichromate, and arsenic pentoxide solution for 3 days.

The treatment of samples for the hot and cold bath method consisted of soaking the specimens in a hot bath $\left(100^{\circ} \mathrm{C}\right)$ of coal tar creosote for 4 hours then allowing the preservative and wood samples to cool down. The specimens remained in the cold bath for 2 days.

After treatment the sample boards were redried for 15 days prior to installation. The test panels were exposed in sea water and instaffed vertically one foot from mud level.

Inspection/assessment was made on the test panels after three years of'sea water exposure for marine borer infestations. T'he samples were evaluated based on the performance rating of five categories as follows :

\section{Description of condition}

Perfectly sound

Trace/slight surface, infestation

Positive/moderate infestation

Deep and extensive infestation

Faffed due to infestation

\section{Rating}

10

9

7

4

0

\section{RESULTS AND DISCUSSION}

\section{Preservative Retention}

The mean values of preservative retention taken from the sample boards are presented in Table 1. Preservative retentions obtained from the medium density wood were significantly higher than the ones from the high density samples. This phenomenon maybe explained by the large cell cavities of the medium than the high density coconut wood which result to, greater absorption and penetration of preservative into the former than the latter sample boards. High density coconut timber is characterized by thick cell wall with relatively small cell cavities.

The retention pattem of preservative significantly varied among treatments/treatment combinations. On water-borne preservative retention, the modified double diffusion $\left(T_{3}\right)$ gave retentions of 21.89 and 29.81 kilograms per cubic meter of dry salt from high and medium density samples, respectively, which were insignificantly different from the samples treated by vacuum/ pressure process $\left(\mathrm{T}_{1}\right)$.

On the other hand, preservative absorption employing the hot and cold bath treatment $\left(\mathrm{T}_{4}\right)$ using oilborne preservative (coal tar creosote) showed retentions of 33.38 and 48.84 kilograms per cubic meter for hard and medium density wood, respectively. 
Table 1. Preservative retention of the test panels. I

\begin{tabular}{|l|c|c|}
\hline \multirow{2}{*}{ Treatment } & \multicolumn{2}{|c|}{ Preservative Retention $(\mathrm{Kg} /$ cu.m) } \\
\cline { 2 - 3 } & High Density & Medium Density \\
\hline $\mathrm{T}_{1}-\mathrm{CCA}$ & $18.12^{\mathrm{b}}$ & $25.27^{\mathrm{b}}$ \\
$\mathrm{T}_{2}-\mathrm{CuSO}_{4}+\mathrm{CrAs}$ & $6.57^{\mathrm{c}}$ & $10.87^{\mathrm{c}}$ \\
$\mathrm{T}_{3}-\mathrm{CuSO}_{4}+\mathrm{CrAs}$ & $21.89^{\mathrm{b}}$ & $29.81^{\mathrm{b}}$ \\
$\mathrm{T}_{4}-\mathrm{CTC}$ & $33.38^{\mathrm{a}}$ & $48.84^{\mathrm{a}}$ \\
$\mathrm{T}_{5}-\mathrm{CCA} / \mathrm{CTC}$ & $42.29^{\mathrm{a}}$ & $57.83^{\mathrm{a}}$ \\
$\mathrm{T}_{6}-\mathrm{CuSO} \mathrm{S}_{4}+\mathrm{CrAs} / \mathrm{CTC}$ & $36.08^{\mathrm{a}}$ & $55.52^{\mathrm{a}}$ \\
$\mathrm{T}_{7}-\mathrm{CuSO} \mathrm{S}_{4}+\mathrm{CrAs} / \mathrm{CRC}$ & $42.41^{\mathrm{a}}$ & $60.49^{\mathrm{a}}$ \\
$\mathrm{T}_{8}-\mathrm{Control}$ & No treatment & \\
\hline $\mathrm{HSD} \mathrm{5 \%}$ & 11.34 & 13.28 \\
$\mathrm{CV}(\%)$ & 14.23 & 10.80 \\
\hline
\end{tabular}

${ }^{1}$ Mean of three replicates. Means having the same letters are significantly different at $1 \%$ level.

The least absorption of preservative was taken from the samples treated by double diffusion process $\left(\mathrm{T}_{2}\right)$ with average dry salt retentions of 6.57 for hard materials and 10.87 kilograms per cubic meter for medium density samples.

Treatments 5, 6 and 7 which received combinations of two treatment methods, first by pressure or non-pressure processes employing water-borne preservative, then retreated by hot and cold bath method with coal tar creosote varied insignificantly on preservative absorption and retentions. However, the highest retentions obtained were from the samples receiving combinations of modified double diffusion and hot and cold bath treatments $\left(\mathrm{T}_{7}\right)$.

\section{Preservative Penetration}

The depth of preservative penetration of the different treatments is piesented in Table 2 . The medium density samples were markedly better penetrated than the hard materials in all the treatments employed. Results showed that the preservative penetration of the modified double diffusion process $\left(\mathrm{T}_{3}\right)$ and its combination with the hot and cold bath method $\left(\mathrm{T}_{7}\right)$ appeared to be significantly higher than the vacuum/pressure method $\left(\mathrm{T}_{1}\right.$ and $\left.\mathrm{T}_{5}\right)$. The former showed preservative penetration of 1.97 and 1.89 centimeters while the latter indicated 1.53 and 1.50 centimeters for high density materials. The depth of preservative penetration for medium density samples was observed to be about $20 \%$ higher than the hard materials.

In contrast, the vacuum/pressure process $\left(\mathrm{T}_{\mathrm{I}}\right.$ and $\left.\mathrm{T}_{5}\right)$ significantly, showed better penetration of preservative than the double diffusion $\left(\mathrm{T}_{2}\right.$ and $\left.\mathrm{T}_{6}\right)$ and hot and cold bath methods $\left(\mathrm{T}_{4}\right)$ giving average penetration of $0.13,1.18$ and 1.16 centimeters, respectively, for high density sample boards.

\section{Performance of Coconut Wood Panels}

The test panels were assessed after three years of exposure to marine borers. Results showed that the treated high density samples performed better than the medium density materials. Ile treated panels appeared to indicate trace to, deep and extensive infestation while the untreated wood samples failed after the exposure period (Table 3 ). 
Table 2. Depth of preservative penetration of coconut wood samples.1

\begin{tabular}{|l|c|c|}
\hline \multirow{2}{*}{ Treatment } & \multicolumn{2}{|c|}{ Preservative Penetration } \\
\cline { 2 - 3 } & High Density & Medium Density \\
\hline $\mathrm{T}_{1}-\mathrm{CCA}$ & $1.53^{\mathrm{b}}$ & $1.90^{\mathrm{b}}$ \\
$\mathrm{T}_{2}-\mathrm{CuSO}_{4}+\mathrm{CrAs}$ & $0.13^{\mathrm{d}}$ & $0.20^{\mathrm{d}}$ \\
$\mathrm{T}_{3}-\mathrm{CuSO}_{4}+\mathrm{CrAs}$ & $1.97^{\mathrm{a}}$ & $2.40^{\mathrm{a}}$ \\
$\mathrm{T}_{4}-\mathrm{CTC}$ & $1.16^{\mathrm{c}}$ & $1.25^{\mathrm{c}}$ \\
$\mathrm{T}_{5}-\mathrm{CCA} / \mathrm{CTC}$ & $1.50^{\mathrm{b}}$ & $1.93^{\mathrm{b}}$ \\
$\mathrm{T}_{6}-\mathrm{CuSO}_{4}+\mathrm{CrAs} / \mathrm{CTC}$ & $1.18^{\mathrm{c}}$ & $1.27^{\mathrm{c}}$ \\
$\mathrm{T}_{7}-\mathrm{CuSO}_{4}+\mathrm{CrAs} / \mathrm{CRC}$ & $1.89^{\mathrm{a}}$ & $2.43^{\mathrm{a}}$ \\
\hline $\mathrm{HSD} \mathrm{5 \%}$ & 0.31 & 0.22 \\
$\mathrm{CV}(\%)$ & 11.02 & 15.98 \\
\hline
\end{tabular}

${ }^{1}$ Mean of three replicates. Means having the same letters are not significantly different at $5 \%$ level.

Comparison among treatment means showed that no significant differences were observed on the performance of the specimens treated by vacuum/pressure $\left(T_{1}\right)$, modified double diffusion $\left(T_{3}\right)$ and hot and cold bath treatments (T4), including their combinations with hot and cold bath treatment using coal tar creosote $\left(\mathrm{T}_{5}, \mathrm{~T}_{6}\right.$ and $\left.\mathrm{T}_{7}\right)$. However, the performance of the aforementioned treatments were markedly better than the double diffusion method $\left(\mathrm{T}_{2}\right)$. Furthermore, no significant differences were noted between double diffusion $\left(\mathrm{T}_{2}\right)$, hot and cold bath $\left(\mathrm{T}_{4}\right)$ and the treatment combinations of double diffusion and hot and cold bath methods $\left(\mathrm{T}_{6}\right)$.

Based on the results of this study, the promising treatments for coconut timber used for marine structures appeared to be the vacuum/pressure and the modified double diffusion processes using water-borne preservatives although the hot and cold bath method employing coal tar creosote could also be effectively employed. The combinations of two treatment methods on coconut timber preservation showed insignificant improvement of its durability against attack of marine borers as shown by the results of this study.

Table 3. Performance of coconut wood panels after three years in sea water exposure. 1

\begin{tabular}{|l|c|c|}
\hline \multirow{2}{*}{ Treatment } & \multicolumn{2}{|c|}{ Preservative Retention $(\mathrm{Kg} / \mathrm{cu} . \mathrm{m})$} \\
\cline { 2 - 3 } & High Density & Medium Density \\
\hline $\mathrm{T}_{1}-\mathrm{CCA}$ & $8.33^{\mathrm{a}}$ & $7.67^{\mathrm{a}}$ \\
$\mathrm{T}_{2}-\mathrm{CuSO}_{4}+\mathrm{CrAs}$ & $4.00^{\mathrm{bc}}$ & $4.00^{\mathrm{b}}$ \\
$\mathrm{T}_{3}-\mathrm{CuSO}_{4}+\mathrm{CrAs}$ & $8.33^{\mathrm{a}}$ & $7.67^{\mathrm{a}}$ \\
$\mathrm{T}_{4}-\mathrm{CTC}$ & $6.67^{\mathrm{ab}}$ & $6.00^{\mathrm{ab}}$ \\
$\mathrm{T}_{5}-\mathrm{CCA} / \mathrm{CTC}$ & $8.33^{\mathrm{a}}$ & $7.67^{\mathrm{a}}$ \\
$\mathrm{T}_{6}-\mathrm{CuSO}_{4}+\mathrm{CrAs} / \mathrm{CTC}$ & $6.67^{\mathrm{ab}}$ & $5.00^{\mathrm{ab}}$ \\
$\mathrm{T}_{7}-\mathrm{CuSO}_{4}+\mathrm{CrAs} / \mathrm{CRC}$ & $8.33^{\mathrm{a}}$ & $7.67^{\mathrm{a}}$ \\
$\mathrm{T}_{8}-\mathrm{Control}^{\mathrm{a}}$ & $1.33^{\mathrm{c}}$ & 0 \\
\hline $\mathrm{HSD} \mathrm{5 \%}$ & 3.83 & 3.42 \\
CV $(\%)$ & 26.62 & 22.29 \\
\hline
\end{tabular}

\footnotetext{
${ }^{1}$ Mean of three replicates. Means having the same letters are not significantly different at $1 \%$ level.
}

${ }^{2}$ Based on rating : 0 to 10 , failure due to marine borers infestation to, sound. 


\section{SUMMARY AND CONCLUSION}

The results of this study revealed that attack of marine borers to coconut wood when exposed to sea water can be controlled or minimized by the application of wood preservatives. Three treatment methods appeared to show promising results. These were the vacuum/pressure process using chromated copper arsenate, the modified double diffusion treatment employing the formulation of copper sulphate, sodium dichromate and arsenic pentoxide, and the hot and cold bath treatment with coal tar creosote.

Although the medium density materials showed markedly higher preservative retention and penetration than the hard specimens, the performance of the foriner appeared to be inferior than the latter when exposed to marine borers' attack. This is an indication that only the hard portion of the coconut palm wood should be used for marine structures. When used in round form, i.e. for piles, the butt portion shotild be solely utilized.
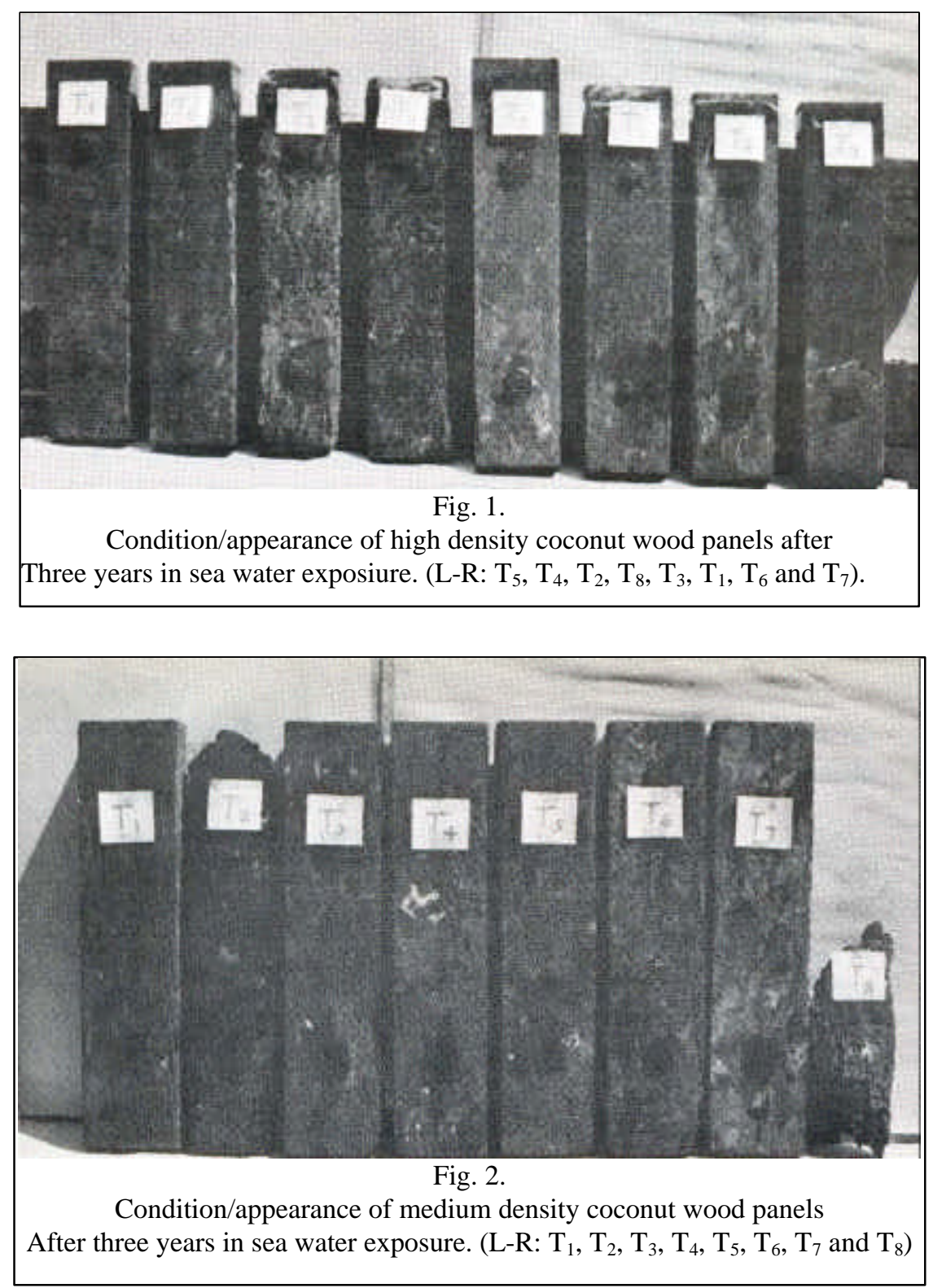


\section{REFERENCES}

Gambetta, A. and Orlandi, E. 1976. Tests on preservation of wood against marine borers. Forest Products Abstracts. Vol. 1, No.12,1978,p.247.

Hockman, H. 1973. Degradation and protection of wood from marine organisms. Wood Deterioration and Its Prevention by Preservative Treatments. Syracuse University Press. Vol. 1, pp. 247-275.

Richards, B. R. 1978. Comparative values of dual-treatment and water-borne preservatives for long range protection of wooden structures from marine borers. Forest Products Abstracts. Vol. 2, No. 2, 1979, p. 31 .

Santhakumaran, L. N. 1977. Incidence of marine wood borers in relation to the angle of the panel. Forest Products Abstracts. Vol. 1, No. 9, 1978, p. 179.

Siriban, F. R., Laxamana, M. G. and Mata, P. G. 1976. Effectiveness of wood preservatives and treatments against marine borers in Philippine waters. Forest Products Abstracts. Vol. 1, No. 11, 1978, p. 220.

Wang, S. F. and Hsieh, T.C. 1976. The durabilities of the important timbers in Taiwan against marine borers and the prevention of their destruction. Forest Products Abstracts. Vol. 1, No. 2, 1978, p. 40. 